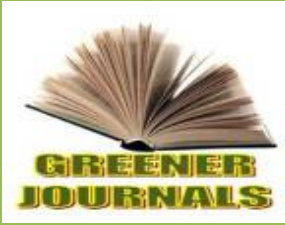

\title{
Status of Forest Coffee (Coffea arabica L.) Diseases in the Afromontane Rainforest Areas of Ethiopia: A review
}

\section{Sihen Getachew}

\author{
Jimma University, Collage of Agriculture and Veterinary Medicine, Horticulture and Plant Science \\ Department, P O Box 307, Jimma, Ethiopia.
}

Article No.: 122616223

DOI: 10.15580/GJAS.2017.1.122616223

Submitted: $26 / 12 / 2016$

Accepted: 03/01/2017

Published: 31/01/2017

${ }^{*}$ Corresponding Author

Sihen Getachew

E-mail: sihengetachew8@gmail.

com

\section{Keywords:}

Coffea Arbica; Diseases; Ethiopia;

Afromontane rainforests; Incidence
Ethiopia, as the center of origin for Coffea arabica, hosts a large diversity of germplasm. Besides drastic reduction in the forest cover and low average yield, the crop is attacked by several diseases, among that coffee leaf rust; coffee berry disease and coffee wilt disease are the major fungal diseases contributing to reduced yield in the country. In this article, the main objective is to provide an overview on current status of major forest coffee diseases prevalence and distributions recorded in afromontane rain forest area of Ethiopia; and to indicate the incidence and severity of forest coffee diseases in the forest coffee populations and elucidates some basic management studies and efforts made to manage those diseases occurred over the past 10 years. The incidences of diseases are reviewed based on different research out puts that was conducted in the afromontane rainforests of the southeast (Harenna) and southwest (Bonga, Berhane-Kontir, Yayu) of Ethiopia. CLR incidences in Ethiopia were present in all forest coffee areas with highest between January and March and lows between June and October with incidence varied from 0.36 to $18.5 \%$ in Bonga, 1.8 to $49 \%$ in Berhane-Kontir, and 11.8 to $62.6 \%$ in Yayu forest coffee populations. The corresponding severity ranged from $0.08-1.2 \%, 0.24-1.7 \%$ and $0.91-3.3 \%$ whereas the Sporulation Lesion density varied from $0.08-1.9,0.33-3.65$ and $1.5-5.9 \%$ in that order. Leaf rust was low (18.5\%) in July 2007 and high (62.6\%) in January 2008. CBD was present mostly in Bonga (40.0\%) and Yayu (26.3\%), but less frequent in Harenna (18.6\%) and Berhane-Kontir $(6.0 \%)$. CWD as a recently developed disease in Arabica coffee could be detected ranging from during the dry season of 2012 , the incidence ranged respectively from 0 to $15.4 \%, 7.3$ to $37.6 \%, 0$ to $22.3 \%$, and 26.4 to 28.3\% in Bonga, Berhane-Kontir, Yayu and Harenna. During the wet season of 2012, the average disease incidence was $11.9,29.2,13.2$ and $27.7 \%$ at the respective forest sites. Significant variation also observed among each coffee tree within a location and season significantly interacted with both location and coffee trees within a location. As researcher indicated in 2010 heterogeneity of forest coffee populations to those diseases in the field under native agro-ecology provides an opportunity to develop resistant varieties among the enormous forest coffee genetic resources and at the same time calls for strategic multi-site in situ conservation to rescue and maintain the present genetic variation and enhance co-evolutionary processes. From this review, in the case of CBD and CWD selections of tolerant Arabica accessions are being pursued from local landraces in afromountan rain forest areas of Ethiopia that undoubtedly needs detailed research work on screening tolerant variety against to the major diseases. 


\section{INTRODUCTION}

The montane rainforests of Ethiopia are the known center of origin and genetic diversity for the highland Arabica coffee (Coffea arabica L.). Arabica coffee is thus a shade adapted plant in the natural multi-strata forest ecosystems with the occurrence of wild Arabica coffee populations (Wrigley, 1988). Ethiopia is endowed with wide ecological suitability and genetic potentials for sustainable production and export of fine quality specialty coffees, while conserving healthy environments. Among the four coffee production systems known in the country, forest and semi-forest coffees are believed to possesses the largest coffee genetic resources (gene pool) followed by the 'landraces' with enormous potential to improve the crop (Sylvain, 1958; Meyer, 1965; Van der Graaff, 1981; Mesfin, 1991; Paulos and Demel, 2000; Gole et al., 2002; Tesfaye, 2006; Tadesse et al., 2008).

Nevertheless, settlement and agricultural landuse pressure have been persistently reducing the remaining forest fragments inhabiting wild coffee populations and other invaluable biodiversity. Poverty and conflicting property rights make farmers convert forests into agricultural or pastoral land, thereby threatening the entire biodiversity of the forests. Consequently, coffee genetic erosion has gone far beyond the point of no return (Mesfin, 1991; Paulos and Demel, 2000; Tadesse et al., 2008). Apart from threats posed by biological and ecological processes, the impact of insect pests and diseases on the forest coffee populations are understood recently in the forest population. However many research findings documented on diseases and insect pest situations in semi-forest, garden and plantation coffee production systems, which originates from the 'wild' forests in Ethiopia (Van der Graaff, 1981; Merdassa, 1986; Eshetu et al., 2000; Girma et al., 2009a). But, in forest coffee populations there is no organized information's regarding with major diseases prevalence and its status until 2006.

Forest coffee is prone to a number of diseases that attack fruits, leaves, stems and roots, and reduce the yield and marketability (Eshetu Derso, 1997). Among diseases, Coffee Leaf Rust (CLR), Hemileia vastatrix, Coffee Berry Disease (CBD), Colletotrichum kahawae and Coffee Wilt Disease (CWD), Gibberella xylarioides (Fusarium xylarioides) are the major disease in Ethiopia.

Coffee berry disease (CBD) is one of the major disease in forest coffee populations, the overall national average loss due to coffee berry disease is estimated to range $25-30 \%$, which amounts to well over 600 million Ethiopian Birr (ETB) or 73.6 million USD ( 1 USD $=8.15$ ETB) per annum (Eshetu Derso, 1997; Eshetu Derso et al., 2000 and Arega, 2006 ). CBD can be controlled by the use of resistant coffee varieties, spraying fungicides or by cultural practices. Developments of resistant varieties save the nation's valuable foreign exchange spent on fungicides (Arega, 2006).
CWD is a vascular wilt disease syndrome, commonly referred to as tracheomycosis and induced by Gibberella xylarioides Heim \& Saccas. Coffee wilt diseas found on Arabica coffee in Ethiopia, mainly in plantations near Agaro, Jimma. The disease incidence is high where coffee is grown under advanced cultural practices and minimal in the less managed forest coffee (Van der Graaff, 1983 and Girma et al., 2009a).

The CABI (2003) technical report indicated that the national incidence and severity of CWD in Ethiopia were $27.9 \%$ and $3 \%$, in monitory terms it causes an estimate loss of more than 3.7 million US dollar annually, respectively. However, the incidence and severity varied from place to place in a range of $0-100 \%$ and $0-25 \%$, respectively.

Sihen et al., (2012) reported that coffee wilt disease is causing significant losses to coffee trees in the main forest coffee systems inhabiting invaluable gene pools of Coffea arabica. The highest incidence of $27.1 \%$ was recorded at Harenna forest coffee in the southeast followed by Berhane-Kontir with $24.9 \%$ in southwest Ethiopia during the dry season of 2008. In the following season, it was more pronounced at BerhaneKontir (29.2\%) albeit similar trend was observed in Harenna forest. Six years back, the mean percent coffee tree death estimated by Arega (2006) was about $2.4 \%$ at Berhane-Kontir while the highest was $17 \%$ at Yayu coffee areas. The overall comparison in CWD progress over the years implicates that the disease pressure is rapidly increasing in the forest coffee systems across all sites, although, slight increment of about two to five percent was recorded during the subsequent wet season.

In addition there were certain variations in the incidence of CWD between coffee fields at each locality that may be ascribed to differences in their genetic makeup and age of coffee cultivars, cultural practices and environmental condition at specific location (Sihen et al., 2012).

CLR caused by Hemileia vastatrix Berkeley \& Broome, was firstly reported in Ethiopia in 1934 (Sylvain, 1955). According to Wondimu (1991) the importance of CLR is increasing with an estimated national percent tree attack of $12.9 \%$ which raised to $36 \%$ after ten years. The epidemics of coffee leaf rust (CLR) was recorded between July 2007 and April 2008 in Bonga, Berhane-Kontir and Yayu montane coffee forest populations of southwest Ethiopia to determine the incidence and severity of CLR and its seasonal variation in the forest coffee populations and their reaction to leaf rust in the natural habitat (Chala et al., 2010).

As Chala et al., (2010) reported that the overall mean incidence of 31.1, 21.4 and 7.9 and SLD of 2.7, 1.8 and 0.86 occurred in Yayu, Berhane-Kontir and Bonga montane coffee forest populations, respectively. Leaf rust was low (13.9\%) in July 2007 and high (29.6\%) in January 2008. Significant variation observed among each coffee tree within a location and season significantly interacted with both location and coffee 
trees within a location. The mean rust incidence varied from 0.36 to $18.5 \%$ in Bonga, 1.8 to $49 \%$ in BerhaneKontir, and 11.8 to $62.6 \%$ in Yayu forest coffee populations.

Today, in a few remaining rainforests of southwest and southeast Ethiopia, coffee grows as an understory shrub in a large diversity of shade trees, shrubs and annual plants and has maintained its own genetic diversity as a natural gene-bank. But this natural resource is faced difficult problem due to those major diseases. It continues, however, to survive all attacks by pathogens and pests in a unique way under natural conditions. Human is one of the major factors to increase the incidence and severities of those three major diseases time to time and cause tremendous losses of coffee tree as indicated by different authors such as; Hindorf (1998); Arega, (2006), Arega et al., (2009); Chala et al., (2010) and Sihen et al., (2012).

Therefore, those reviews give the crucial information about the current status of those disease occurrence and prevalence of diseases by concentrating on management practice in the montane rainforests of Ethiopia. This genetic potential not only saved lots of expenditure on the purchase of fungicides and spray equipment but also prevented the risk of pesticides hazards to our farmers and the environment.

Hence, screening of promising forest coffee seedlings are curtail and environmentally friendly for developing best management options. Therefore, the main objectives of this review is to provide an overview on current status of major coffee diseases prevalence and distributions recorded in montane rain forest area of Ethiopia; and to indicate the incidence and severity of forest coffee diseases in the forest coffee populations and elucidates some basic management studies and efforts made to manage those diseases occurred over the past 10 years. These forest coffee areas contain a large genetic pool of Arabica coffee representing a potential source for the benefit of present and future human generations.

\section{STATUSES OF COFFEE DISEASES IN THE AFROMONTANE RAINFORESTS AREA OF ETHIOPIA}

The three major diseases of coffee, namely coffee berry disease (CBD), coffee wilt disease (CWD) and coffee leaf rust (CLR) were found in association with forest coffee in Harenna, Bonga, Berhane- Kontir and Yayu montane rainforests of Ethiopia (Fig. 1). Leaf blight, Ascochyta tarda Stewart and coffee bean darkening or bacterial blight,

Pseudomonas syringae pv. garcae (Amaral, Teixeira \& Pinheiro) Young, Dye \& Wilkie were also observed in the forest coffee, but not scored during 2009 survey period (Arega Z. et al., 2009).

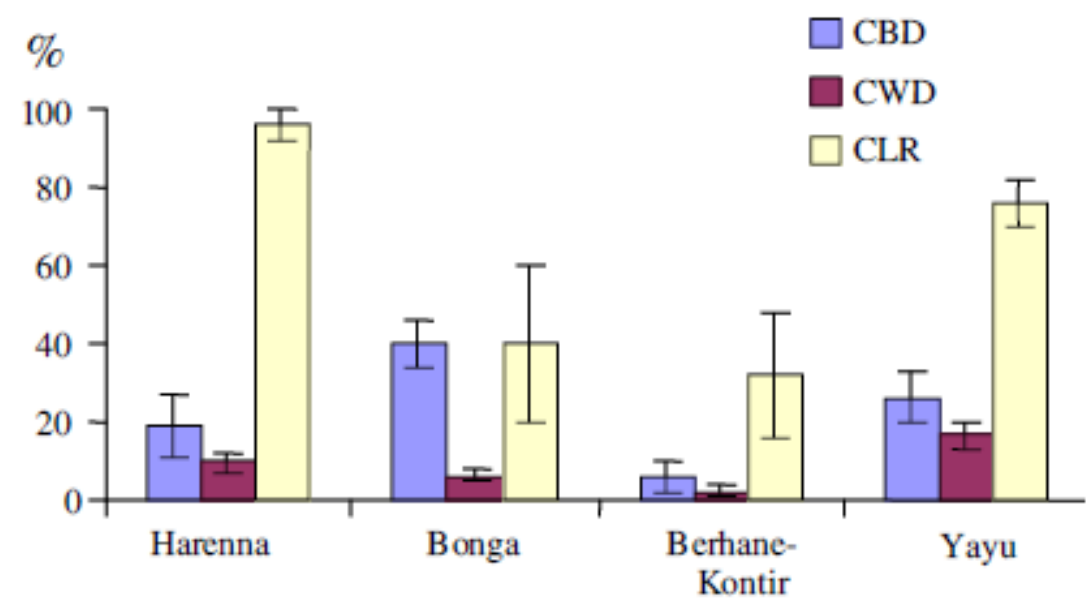

Fig. 1: Occurrence of Coffee Berry Disease (CBD), Coffee Wilt Disease (CWD) and Coffee Leaf Rust (CLR) in montane rainforest coffee of Ethiopia (error bars are standard errors). Source: (Arega Z. et al., 2009).

\subsection{Status of CLR in the Afromontane rainforest coffee of Ethiopia}

\subsubsection{Distributions of coffee leaf rust in forest coffee systems}

As Arega Z. et al., (2009) reported in all investigated forest coffee areas coffee leaf rust (CLR) was prevalent to a high extent (around $96 \%$ (Fig.1). The assessments results counting exactly the number of infected trees for the frequency and scoring the intensity on single infected leaves, showed more or less high frequencies of CLR in all forest coffee areas varying from $32.2 \%$ at Berhane-Kontir to $96 \%$ at Harenna forest coffee (Fig. 1). 
The highest CLR frequency occurred in 2005 at Harenna followed by Yayu. Young seedlings under the forest coffee at Harenna were covered completely with rust sori influencing the survival and further growth. In addition to the annual disease occurrence in 2005 we present data on the intensity of CLR during the complete observation period from 2003 - 2007.

Coffee leaf rust assessment were made again in 2007 and 2008 in three southwestern Ethiopian montane coffee forest populations revealed its presence in all fields assessed differing in magnitude with time (season) and location of the forest coffees (Chala J. et al., 2010). A significantly $(P<0.001)$ high rust incidence of $31.1 \%$ was recorded, for instance, in 2008 at Yayu, followed by
Berhane-Kontir (21.4\%) and Bonga ( $7.9 \%$ ) in forest coffee populations. Rust incidences were consistently highest in Yayu, lower in Berhane-Kontir and lowest in Bonga forests during all seasons (fig. 3).

The occurrence of rust in the forest coffee populations varied significantly from season to season $(P<0.001)$. Higher rust incidences were found in January (29.6\%) and April (22.7\%), while lower incidences were observed in July (13.9\%) and October (14.3\%).

Comparing rust occurrence during the complete period of the surveys from 2003 to 2008 a slight increase of the disease could be reported in 2009 in the wild coffee population.

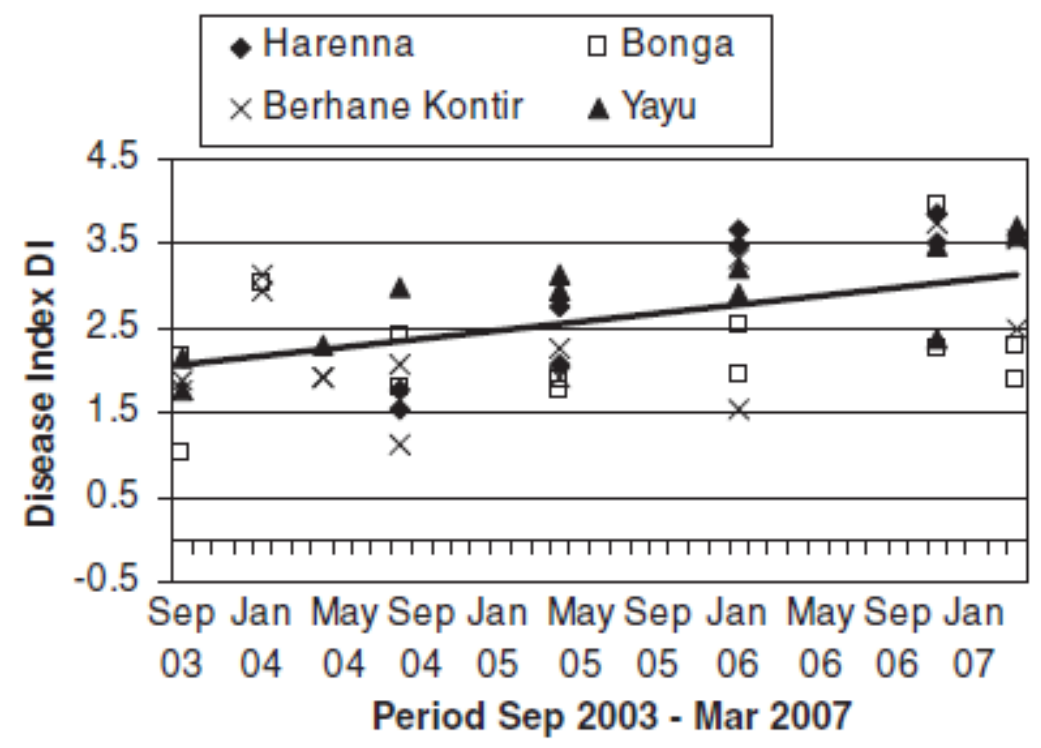

Fig. 2 CLR severity during 2003 and 2007 in indigenous coffee populations of Ethiopia

Source: Arega Z. et al., (2009)

Chala J. et al., (2010) reported that reaction of coffee trees to CLR infection within a location was significantly different $(P<0.001)$. Rust incidence varied from 0.36$18.5 \%$ in Bonga, 1.8-49\% in Berhane-Kontir, and 11.8$62.6 \%$ in Yayu forest coffee populations. There was no coffee tree that showed greater than $20 \%$ rust incidence in Bonga. On the other hand, there were only three coffee trees (Y2, Y14, and Y27) that had less than 19\% rust infection among the evaluated Yayu forest coffee population's Coffee tree infection by CLR varied from among months and some forest coffee trees had as high as $69 \%$ rust incidence in January 2008 but less than $3 \%$ incidence in July 2007. 


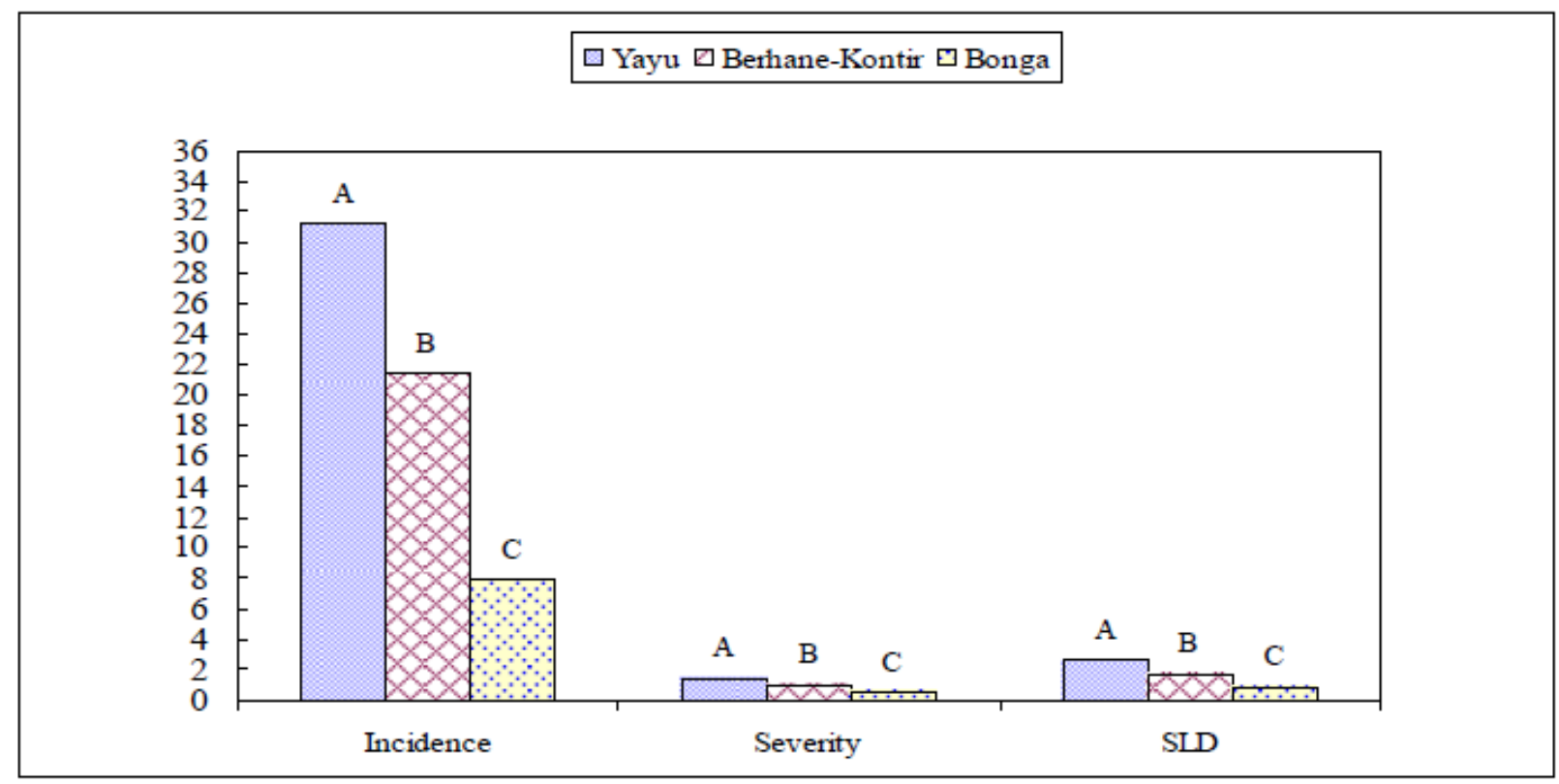

Figure 3 Coffee leaf rust incidence (\%), severity (\%) and sporulation lesion density (SLD) in three montane forest coffee populations of southwestern Ethiopia (July 2007-April 2008).

(Chala J. et al., 2010)

As Chala J., et al., (2010) showed that the occurrence of CLR varied from location to location and its incidence was high in Yayu followed by Berhane-Kontir and Bonga forest coffee population.

Arega et al., (2009) also reported higher rust incidence in Yayu than in Bonga forest coffee population. These variations across forests were attributed to human activities, altitude and environmental gradients across the location. Inadvertent human activities such as transformation of the intact natural forest to semi-forest production system for improving productivity and coffee farmland expansion, exclusive thinning of over story trees, slashing of weeds and shrubs (at least twice a year in Berhane-Kontir), adjusting coffee tree population using self-regenerated coffee trees and seedlings might have increased the transmission and contact of the rust pathogen within the forest coffee trees. Soto-Pinto et al. (2002) reported significantly higher rust incidence in plots where paths were present than plots without paths in the forest.
The differences in rust incidence, severity and SLD across the forest coffee populations were also related to variation in altitude. Studied fields in Yayu and Berhane-Kontir forest coffee populations were situated at an altitude less than 1200 masl, whereas the Bonga forest fields were found between 1620 and 1870 masl. Simple linear correlation analysis based on data set in this report revealed inverse relationship between rust incidence and altitude but not significant. Nevertheless, the effect of altitude on the development of CLR was reported by several researchers (Kushalappa, 1989; King'ori and Masaba, 1994; Brown et al., 1995; Meseret, 1996). Rust incidence decreased with increase in altitude and, at higher altitudes, the low night temperatures followed by still low day temperatures resulted in a longer latent period and slower epidemic, while it hasten rust development in low altitude belts (Chala J. et al., 2010). 

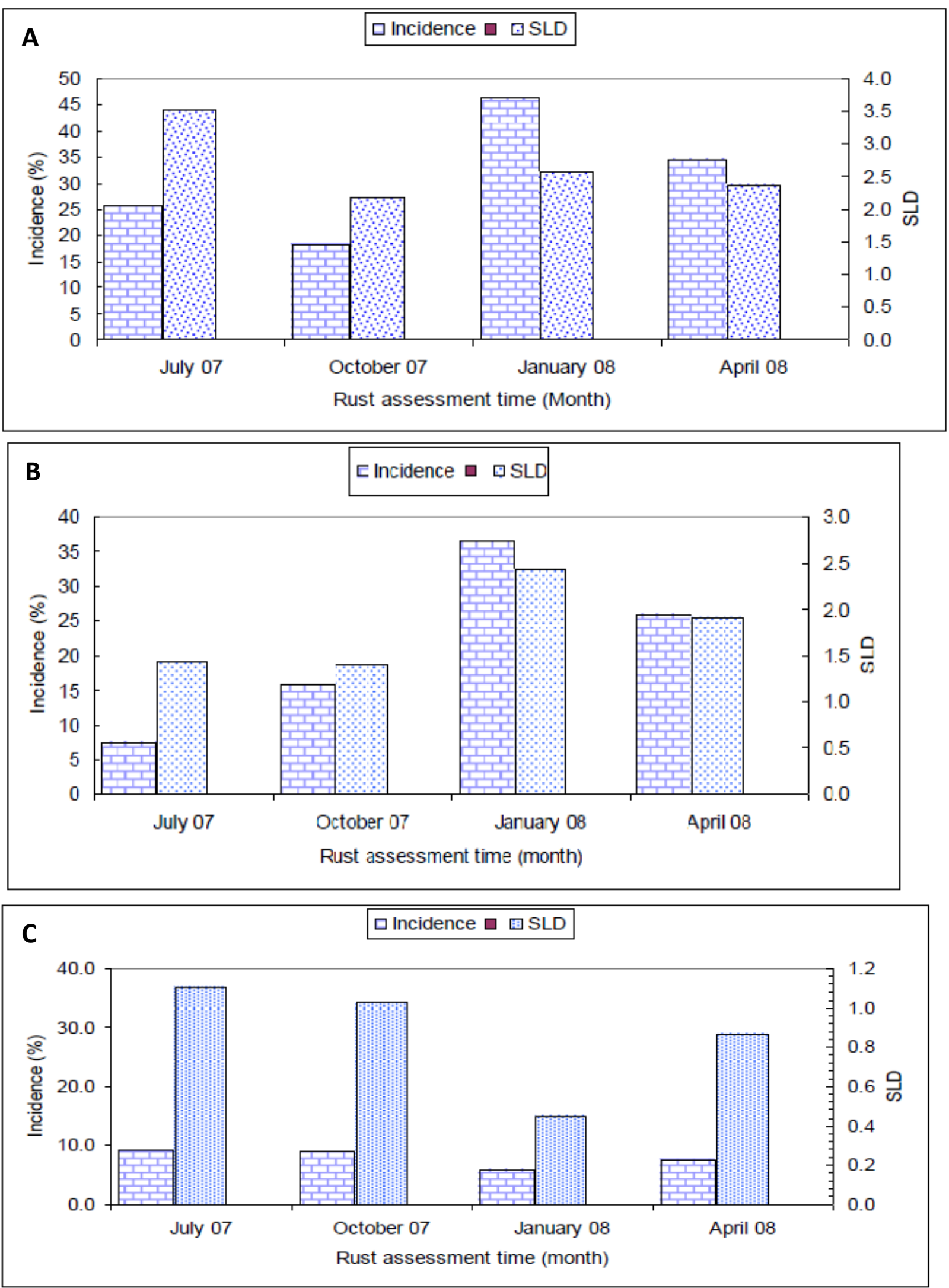

Figure 4. Coffee leaf rust incidence (I) and sporulated lesion density (SLD) in Yayu (a), Berhane-Kontir (B) and Bonga (c) over four selected months during 2007 and 2008 (Chala J. et al., 2010) 
In general, as the report indicated coffee leaf rust was present in all assessed forest coffee populations, but significantly varied from location to location and among months as well. The level of coffee tree infection by CLR was also significantly varied among each other indicating variability of each coffee tree from location to location and within a location in response to rust infection. The observed significant coffee tree by month interaction implied variation in conduciveness of environment for rust development over time (month) (Fig. 4). This may also emanate from the existence of quantitative variations in both host and pathogen in different environmental combinations.

The significant variation of indigenous forest coffee trees in reaction to CLR, its responsiveness to environmental instability and variation in leaf age might have synergistically induced significant forest coffee tree-environment-interaction which is little understood under natural pathosystem. In these recurring natural rust forest coffee system, coherent investigations with introduction of modifications into the natural system is suggested (Chala J. et al., 2010).

The interaction effects also necessitate characterization of Hemileia vastatrix races prevalent at each location to persevere strategic variety development for contrasting environments. The existence of heterogeneous montane coffee forests to rust in the field under native agro-ecology is an asset to develop resistant varieties among the enormous forest coffee genetic resources and calls for strategic in situ conservation to rescue and maintain the present variation (Chala J. et al., 2010).

\subsection{Status of $C B D$ in the Afromontane rainforest coffee of Ethiopia}

\subsubsection{Distributions of coffee berry disease in forest coffee systems}

Information concerning the incidence of CBD in the Ethiopian forest coffee regions of Harenna, Bonga, Berhane-Kontir and Yayu is presented. Assessments of the incidence (infected trees per locality) and severity (infestation of single trees) were scored visually. The CBD occurrence depended mostly on altitude ranges; higher sites were more frequently infected than lower sites due to more favorable climatic conditions for the pathogen (Arega Z. 2006).

Arega Z. (2006) reported that the frequency and intensity of CBD varied among and within forest coffee areas depending on environmental condition and genetic diversity of forest Arabica coffee. Coffee berry disease was observed in Yayu and Bonga forest coffee consistently. In Yayu it was also found at low altitude but the intensity was lower than the higher altitude. In Sheko and Bale, the disease was found in pocket areas (limited areas) of the forest coffee areas.

Survey results indicated that the disease incidence ranged $0-50 \%, 20-60 \%, 0-20 \%$ and $0-50 \%$ and severity $0-15 \%, 12.5-22.5 \%, 0-6.5 \%$ and $0-7.8 \%$ were observed in forest coffee areas of Bale, Bonga, Sheko and Yayu, respectively. The mean incidence ranged between $6.0 \%$ at Sheko and $40.0 \%$ at Bonga whereas the intensity of the disease varied between 2.0 and $17.9 \%$ at Sheko and Bonga, respectively (Fig. 5)

High frequencies of CBD may be explained by particularly high rainfall found in relatively high altitudes of Bonga and to some extent in Yayu. Similarly, Cook (1975) explained that high rainfall, high humidity or wetness and relatively low temperatures persisting for long periods and favoring the CBD development are existing at higher altitudes, where these conditions generally prevail. In addition to expected results in Yayu the disease was also found at low altitudes $(<1500$ m.a.s.l) ranging from a frequency of 0 to $40 \%$, but achieved a frequency up to $50 \%$ in medium altitudes.

This indicated that CBD can be very important in lower altitudes too. There occurred no CBD at low lands of Harenna (around Majete) and Berhane-Kontir (around Gizmeret) forest coffee areas So, the CBD occurrence depended mostly on altitude ranges; higher sites were more frequently infected than lower sites due to more favorable climatic conditions for the pathogen (Arega. et al., 2009). 


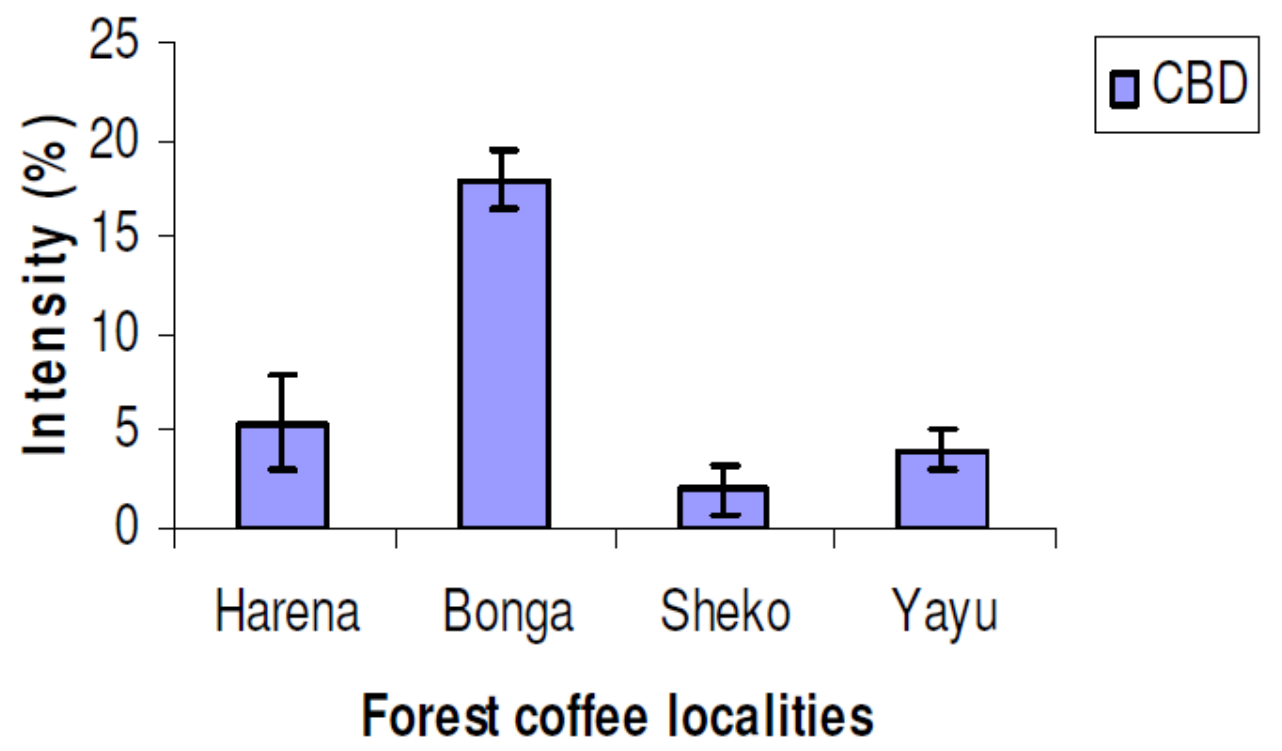

Figure 5. Intensity of CBD in afromontane rainforest coffee areas of Ethiopia (error bars are standard errors).

Source: Arega Z. (2006)

\subsubsection{Seedling Inoculation Tests of Forest Coffee accessions}

The pathogenicity of CBD isolates was not only tested on detached berries in the laboratory but also on seedlings in the greenhouse to investigate the diversity of coffee grown under natural conditions. Seedlings from seeds collected in Harenna, for instance, produced in the lower site 2 incidence rates of $23.3 \%$ and proved to be as similarly resistant/tolerant as resistant cultivars such as cv. 754 and 741 . In contrast, on the higher site 3 of the same region only one tree with a lower intensity of $27.3 \%$ berries infected by the pathogen of CBD was found; all the other nine trees were highly susceptible (Holger H. and Chrispine O., 2010).

Due to the fact that CBD was present in the surroundings of the Bonga and Yayu sites it was decided to carry out attached berry tests directly in the field, a well-documented method of testing CBD resistance. The infection tests on attached berries in the field sites of Bonga and Yayu produced a large diversity in susceptibility. Infection rates at Bonga varied in 2004 between $0 \%$ and $47.0 \%$ and in 2005 between $7.9 \%$ and $81.5 \%$. Coffee trees were less susceptible at Bonga than at Yayu.

In addition to this, in 2006 as Arega Z., reported that indigenous forest coffee selections that selected from 4 different forest coffee areas revealed significant variations among them in percent $\mathrm{CBD}$ infection. Selections from Yayu, Bonga, Berhane-Kontir (Sheko) and Harena (Bale) showed mean seedling infection rate, $69.0-100 \% \quad 57.5-100 \%, 75.3-100 \%$ and $23.3-100 \%$, respectively (Table 1 ). The result indicated that there existed widest range of infection rate among Harena selections followed by Bonga and Yayu selections.

But a difference in disease infection level among Sheko selections was very narrow even if statistically significant, $60 \%$ of the tested selections depicted the same significant level with that of the standard susceptible check. This result indicated that there existed variations among selections that selected from all sites generally and there was also a variation within individual coffee selections of each forest coffee population (locality) in reaction to CBD (Arega, 2006). 


\begin{tabular}{|c|c|c|c|c|c|}
\hline \multicolumn{6}{|c|}{ Coffea Arabica cultivar } \\
\hline Isolate1 & 741 & 754 & 74110 & 370 & Mean2 \\
\hline $\mathrm{H} 40$ & $14.0 \mathrm{~d}$ & $20.3 \mathrm{~g}$ & $88.7 b-d$ & $100 \mathrm{a}$ & $55.8 \mathrm{AB}$ \\
\hline H41 & $12.7 \mathrm{gh}$ & $17.8 \mathrm{gh}$ & $85.3 \mathrm{~b}$ & $100 \mathrm{a}$ & $54.0 \mathrm{~A}-\mathrm{C}$ \\
\hline $\mathrm{H} 43$ & $14.2 \mathrm{gh}$ & $15.4 \mathrm{gh}$ & $78.3 d-f$ & $98.0 \mathrm{a}$ & 51.5 CD \\
\hline B52 & $20.2 \mathrm{~g}$ & $17.9 \mathrm{gh}$ & 89.5 bc & $100 \mathrm{a}$ & $56.9 \mathrm{~A}$ \\
\hline B53 & $16.5 \mathrm{gh}$ & $13.8 \mathrm{gh}$ & 86.6 b- e & $100 \mathrm{a}$ & $54.2 \mathrm{~A}-\mathrm{C}$ \\
\hline B55 & $17.7 \mathrm{gh}$ & $17.7 \mathrm{gh}$ & $77.8 \mathrm{df}$ & $98.3 \mathrm{a}$ & $53.2 \mathrm{~B} D$ \\
\hline $\mathrm{S} 60$ & $12.3 \mathrm{gh}$ & $13.7 \mathrm{gh}$ & $80.3 \mathrm{c}$ & $f 100 a$ & 51.6 B D \\
\hline S61 & $10.7 \mathrm{gh}$ & $14.3 \mathrm{gh}$ & 76.9 ef & $97.6 \mathrm{a}$ & $49.9 \mathrm{D}$ \\
\hline Y70 & $9.0 \mathrm{~h}$ & $15.0 \mathrm{gh}$ & $79.0 \mathrm{df}$ & $100 \mathrm{a}$ & $79.0 \mathrm{~d}$ \\
\hline Y73 & $14.6 \mathrm{gh}$ & $18.5 \mathrm{gh}$ & $92.7 \mathrm{~b}$ & 98.3 a & $56.0 \mathrm{AB}$ \\
\hline Y75 & $16.0 \mathrm{gh}$ & $10.8 \mathrm{gh}$ & $21.0 \mathrm{~g}$ & $70.3 \mathrm{f}$ & $29.5 \mathrm{E}$ \\
\hline G81 & $21.8 \mathrm{~g}$ & $9.3 \mathrm{~h}$ & $79.3 \mathrm{df}$ & $98.3 \mathrm{a}$ & 52.2 B D \\
\hline Mean' $^{2}$ & $15.0 \mathrm{~L}$ & $15.5 \mathrm{~L}$ & $78.0 \mathrm{~K}$ & $96.7 \mathrm{~J}$ & \\
\hline
\end{tabular}

Source: Arega Z. 2006

Considerable variation also examined among forest coffee selections in percent infection of attached berries in ABT conducted on Yayu and Bonga forest coffee selections in the field. Percent infection of berries varied between 1.4 and $81.5 \%$ at Bonga, and between 4.7 and $61.4 \%$ at Yayu. 13 and 16 selections from Yayu and Bonga showed low level of infection (<30\%), 4.7-26.6\% and $1.4-25.6 \%$, respectively, as compared to others.

So, it is important to conserve the forest indigenous coffee germplasms both insitu and exsitu and use sustainably by first applying intensive selection from more diverse coffee population and evaluation for diseases resistant (with particular focuses for major diseases, CBD, CLR and CWD), high yield, better quality and other characteristics to enhance the production and productivity of coffee in Ethiopia and in the world.
2.3. Status of CWD G. xylarioides (F. xylarioides) in forest coffee area

\subsubsection{Distributions and occurrence of coffee wilt disease in forest coffee systems}

Coffee wilt disease was prevalent in forest coffee systems in the southwest and the southeast Ethiopia. The disease incidence varied from field to field and from one survey area to the other. During the dry season of 2008 , the incidence ranged respectively from 0 to $15.4 \%, 7.3$ to $37.6 \%, 0$ to $22.3 \%$, and 26.4 to $28.3 \%$ in Bonga, Berhane-Kontir, Yayu and Harenna (Fig. 6). During the wet season of 2009, the average disease incidence was $11.9,29.2,13.2$ and $27.7 \%$ at the respective forest sites (Fig. 7).

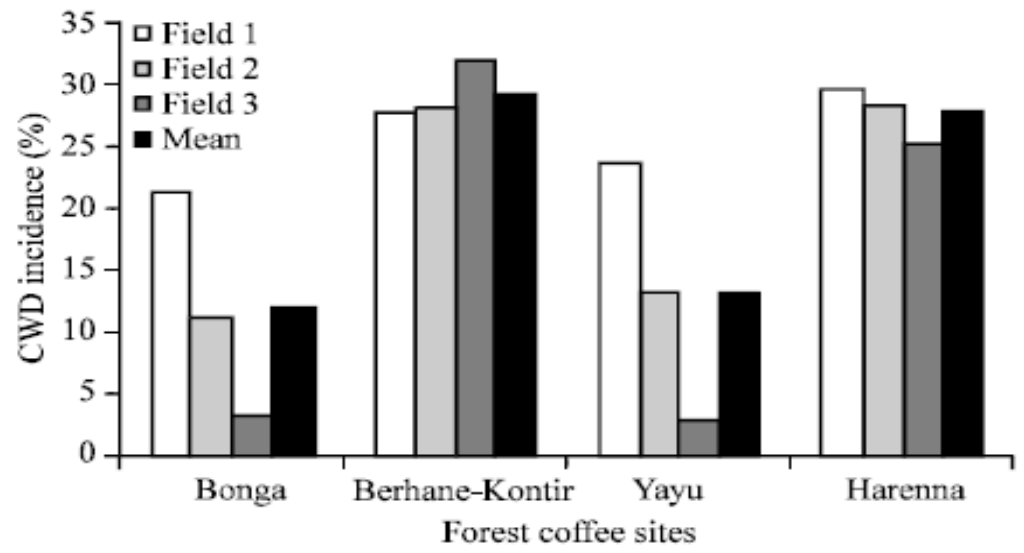

Fig. 6: Incidence of coffee wilt disease (CWD) in different fields of four forest coffee sites of southwest and southeast Ethiopia in dry season, 2008 
During the period of assessments of the disease in 2004-2012, CWD was detected in all the indigenous coffee field sites. The lowest percentage of infected trees was found in Berhane-Kontir, the highest in Yayu. Comparing coffee wilt disease occurrence during the complete period of the surveys from 2004-2012, considerable increment of the disease could be observed in Berhane-Kontir and Yayu by the percentage of 7.3 to $37.6 \%, 0$ to $22.3 \%$, at the respective wild coffee areas of Ethiopia (Sihen et al., 2012).

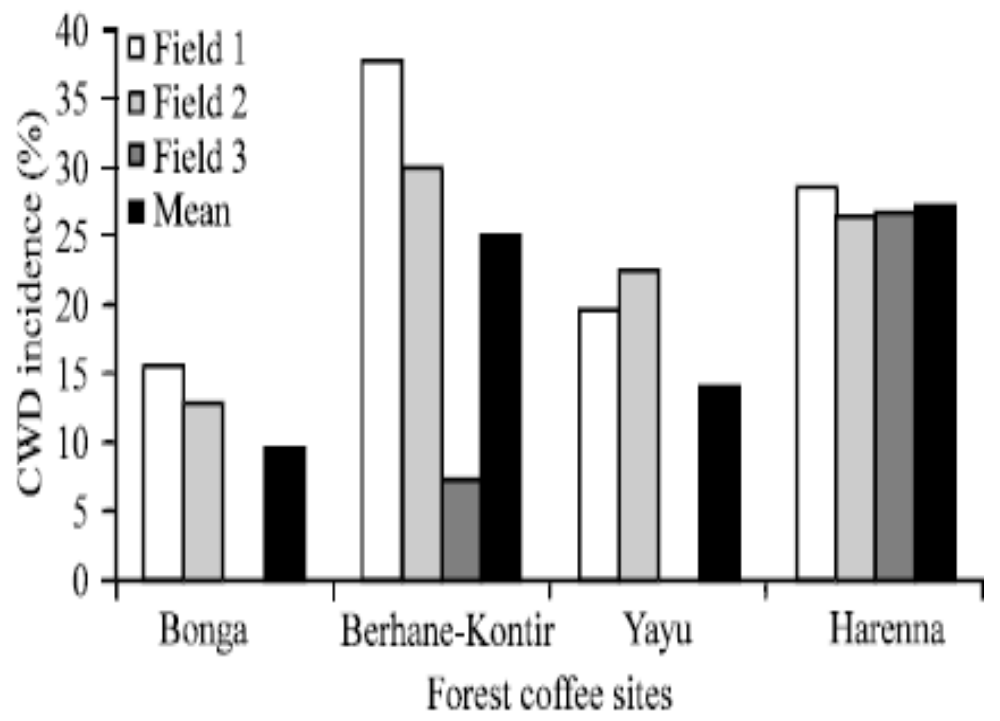

Fig. 7: Incidence of coffee wilt disease (CWD) in different fields of the forest coffee sites of southwest and southeast Ethiopia in wet season, 2009

Source: (Sihen et al., 2012)

\subsubsection{Seedling Inoculation Tests of Forest Coffee accessions}

Sihen et al., (2012) reported that seedling inoculation test results showed that there existed significant differences among the tested accessions, and most of the coffee accessions collected from Harenna appeared to be highly resistant to CWD with infection rates between $0 \%$ and $10.0 \%$. On the contrary, most coffee accessions obtained from Bonga, Berhane-Kontir and Yayu showed significantly $(p<0.05)$ higher seedling deaths of about 80 percent as compared to the standard susceptible control 'SN-5' Seedlings of coffee accessions possessing moderate to high resistance to the CWD pathogen were grown, re-inoculated with the same fungus isolate and transferred to greenhouse and field sites for further observation.

Results of greenhouse inoculation experiments proved that there was important diversity in coffee populations (within and among the forest sites) in reaction to G. xylarioides infection (Arega Z., 2006; Sihen et al., 2012 and Sihen et al., 2013). However, there is a tendency towards occurrence of higher frequency of susceptibility reactions except in Harenna coffee populations that consistently revealed higher level of resistance in both sets of experiments, even despite the fact that relatively more CWD incidence recorded in the fields.

As host-pathogen interaction results reported by Sihen et al., (2013) the accession versus isolate interactions demonstrated differential effects, and thus, seedlings of Harenna accessions (P4, P6 and P11) were horizontally resistant $(<30 \%)$ to almost all isolates of $G$. xylarioides but susceptible to the isolate originated from the same site $(\mathrm{H} 11)$ which induced $90 \%$ seedling death. In contrast, Yayu accessions (P47, P49 and P59) were highly resistant only to Berhane-Kontir isolate ( $\mathrm{SH} 21)$ without expressing any wilt symptoms (0.0\%); although, they are susceptible to the other four isolates, namely, 'B23', 'Y21', and 'H11' and 'G11' with varying disease levels.

With respect to the differential effect of the pathogen isolates, the Harenna isolate $(\mathrm{H} 11)$ induced higher death rates (up to $90 \%$ ) on all accessions including the moderately resistant check ' $c v$. 7440' being horizontally pathogenic strain. On the other hand, the Berhane-Kontir isolate ' $\mathrm{SH} 21$ ' was not or weakly pathogenic to the seedlings of Harenna and Yayu accessions (P4 to P11, P47 to P59) and the check cultivar ( $\mathrm{Cv} .7440$ ) without any apparent symptoms of wilt $(0.0 \%)$. The southwest forest coffee isolates 'B23' and ' $Y 21$ ' showed similar aggressiveness as that of Gera strain 'G11' pathogenic to the seedlings of all coffee 
accessions. It was found in this study that, on average, isolate ' $\mathrm{H} 11$ ' with faster growth were more aggressive than those with slow growth rate agreeing with earlier report by Girma and Mengistu (2000).

Arega Z., (2006) also reported similar findings that $50 \%$ (five out of ten) of Harenna coffee collections showed less than $15 \%$ seedling deaths, as opposed to coffee accessions collected in Bonga (16\%), BerhaneKontir (20\%) and Yayu (20\%) forest areas which showed more than $85 \%$ average infections. The inconsistent response of Harenna coffee populations in the field and the greenhouse conditions could perhaps be the difference in

Aggressiveness of the pathogen isolates used in the seedling inoculation tests, as they were originated from southwest Ethiopia. This in turn warrants studying host pathogen interactions among coffee accessions and the pathogen strains representing forest coffee systems, as variations in aggressiveness among the pathogen populations was already reported by a number of workers (Adugna et al., 2005; Girma et al., 2009b; Rutherford et al., 2009).

In general, the recent assessment supported by detailed diagnosis coupled with frequent isolation and identification of the causal pathogen Gibberella xylarioides, coffee wilt disease is proved to be prevalent in the forest coffee systems in southwest and southeast Ethiopia. The disease incidence, although varying from field to field and from one forest coffee site to the other, has been increasing spatially and temporally thereby becoming one of the major factors threatening forest coffee genetic resources. It is decimating those coffee trees that perhaps possessing resistances to other diseases, insect pests and nematodes; with good yield and quality.

\section{CONCLUSION AND SUGGESTIONS}

Currently in Ethiopia most forest coffee trees are less productive because of variable factors, among that diseases are the major constraints which threatening forest coffee genetic resources. These major diseases are coffee leaf rust, coffee wilt disease and coffee berry diseases are becoming important and that occurs with varying degree of infestation and distribution in the main forest area of Ethiopia. Thus, the forest coffee conservation strategies should take the disease into account and apply the recommended principles and practices of disease management

Development of resistant Arabica coffee varieties through large-scale collection and screening against the pathogen would be inevitable, although it seems that most coffee trees exhibit susceptibility in the forest coffee populations. In this line, investigation in the area of developing resistant varieties, biocontrol agents, use of proper cultural practices and screening effective chemicals as a last resort or use of these techniques in integrated pest and disease management (IPDM) strategy could minimize the damage caused by diseases and would definitely conserve coffee genetic pools and facilitate utilization of Arabica coffee genetic resources at their place of origin in natural rainforests for global benefits.

It is important that prior to their release to coffee growers, newly CBD CWD and CLR resistant coffee types should also be tested for their level of resistance to those diseases particularly coffee wilt and coffee leaf rust.

Therefore, employing effective, easily applicable, environmentally sound and economically feasible control approaches should be exercised for disease management of Arabica coffee in forest populations of Ethiopia.

\section{ACKNOWLEDGEMENTS}

I would like to thank the authors and their partners for carrying out most of the research work: Arega Zeru, Chala Jefuka, Dr. Gima Adugna, Holger Hindorf and Chrispine O. Omondi in Ethiopia and German for providing working facilities in the laboratory and field sites for researchers which has formed a major basis of the review on current situation of the disease.

\section{REFERENCES}

Adugna, G., H. Hindorf, U. Steiner, H.I. Nirenberg, H.W. Dehne and K. Schellander, 2005. Genetic diversity in the coffee wilt pathogen (Gibberella xylarioides) polpulations: Differentiation by host specialization and RAPD analysis. J. Plant Dis. Prot., 112: 134145.

Arega, Z., 2006. Diversity of arabica coffee populations in afromontane rainforests of Ethiopia in relation to Colletotrichum kahawae and Gibberella xylarioides. M.Sc. Thesis, Addis Ababa University, Ethiopia.

Arega, Z., F. Assefa, G. Adugna and H. Hindorf , 2009. Occurrence of fungal diseases of Coffea arabica $\mathrm{L}$. in montane rainforests of Ethiopia. Journal of Applied Botany and Food Quality 82, 148 - 151

Brown, J.S., Kenny, M.K., Whan, J.H. and Marrian, P.R. 1995. The effect of temperature on the development of epidemics of coffee leaf rust in Papua New Guinea. Crop Protection 14 (8): 671-676.

CAB International, 2003. Surveys to assess the extent and impact of coffee wilt disease in East and central Africa. Final Technical Report. CABI Regional Centre, Nairobi, Kenya.

Chala Jefuka, Chemeda Fininsa, Girma Adugna and Holger Hindorf. 2010. Coffee Leaf Rust Epidemics (Hemileia vastatrix) in Montane Coffee (Coffea arabica L.) Forests in Southwestern Ethiopia. East African Journal of Sciences. 4 (2) 86-95. 
Cook, R.T.A., 1975: Screening coffee plants for resistance to CBD. Annual Report CRF Ruiru/Kenya.

Eshetu Derso. 1997. Coffee diseases and their significance in Ethiopia. ASIC 17(I):723-726.

Eshetu, D., G. Teame and A. Girma, 2000. Significance of minor diseases of Coffea arabica L. in Ethiopia: A review. Proceedings of the Workshop on Control of Coffee Berry Disease (CBD) in Ethiopia, August 1315, 1999, Agricultural Research Organization, Addis Ababa, Ethiopia, pp: 58-65.

Girma, A., D. Bieysse and P. Musoli, 2009a. HostPathogen Interactions in Coffea-Gibberella xylarioides Pathosystem. In: Coffee Wilt Disease, Flood, J. (Ed.). CAB International, Wallingford, UK., pp: 120-136.

Girma, A., M. Abebe, H. Hindorf, Z. Arega, D. Teferi and C. Jefuka, 2009b. Coffee Wilt Disease in Ethiopia. In: Coffee Wilt Disease, Flood, J. (Ed.). CAB International, Wallingford, UK., pp: 50-68.

Girma, A. and Mengstu. H. 2000. Cultural characteristics and pathogenicity of Gibberella xylarioides isolates in coffee. Pest Mgt. J. Ethiopia, 4: 11-18.

Gole, T.W., M. Denich, D. Teketay and P.L.G. Vlek, 2002. Human Impacts on Coffea arabica Genetic Pool in Ethiopia and The Need For its in situ Conservation. In: Managing Plant Genetic Diversity, Engels, J., V.R. Rao, A.H.D. Brown and M. Jackson (Eds.).

Hindorf H. 1998. Current diseases of Coffea arabica and C. canephora in East Africa causing crop losses. Meded Fac Landbouwwet Univ Gent 1998;63:8615.

Holger Hindorf and Chrispine O. Omondi. 2011. A review of three major fungal diseases of Coffea Arabica $L$. in the rainforests of Ethiopia and progress in breeding for resistance in Kenya. Journal of Advanced Research (2011) 2, 109-120.

King'ori, P.N. and Masaba, D.M. 1994. Current status of coffee rust (Hemileia vastatrix) in Kenya. Kenya Coffee 59(697): 1877-1887.

Kushalappa, A.C. 1989. Biology and epidemiology. In: Kushalappa, A.C. and Eskes, A.B. (eds.). Coffee Rust: Epidemiology, Resistance and Management; CRC Press Inc., Florida. pp. 13-80.

Kufa, T. and Jurgen B., 2013. Studies on root growth of Coffea arabica populations and its implication for sustainable management of natural forests. Journal of Agricultural and Crop Research, 1:1-19.

Kufa, T. and J. Burkhardt, 2011. Spatial variability in water relations of wild Coffea arabica populations in the montane rainforests of Ethiopia. Ecologia, 1: 3143.

Merdassa, E., 1986. A Review of Coffee Diseases and Their Control in Ethiopia. In: First Ethiopian Crop Protection Symposium, Abate, T. (Ed.). Institute of Agricultural Research, Addis Ababa, Ethiopia, pp: 187-195.

Mesfin, A., 1991. Significance of Ethiopian Coffee Genetic Resources to Coffee Improvement. In: Plant
Genetic Resources of Ethiopia, Engels, J.M.M., J.G. Hawkes and M. Worede (Eds.). Cambridge University Press, Cambridge, pp: 354-359.

Meseret, W. 1996. Coffee leaf rust epidemiology and management in Ethiopia. PhD Dissertation, Imperial College of Science and Technology, London. pp. 304.

Meyer, F.G., 1965. Notes on wild Coffea arabica from southwestern Ethiopia, with some historical considerations. Econ. Bot., 19: 136-151.

Paulos, D. and T. Demel, 2000. The need for forest germplasm conservation in Ethiopia and its significance in the control of coffee diseases. Proceedings of the Workshop on Control of Coffee Berry Disease (CBD) in Ethiopia, August 13-15, 1999, Agricultural Research Organization, Addis Ababa, Ethiopia, pp: 125-135.

Rutherford, M.A., D. Bieysse, P. Lepoint and H.M.M. Maraite. 2009. Biology, Taxonomy and Epidemiology of the Coffee Wilt Pathogen Gibberella xylarioides Sensu Lato. In: Coffee Wilt Disease, Flood, J. (Ed.). CAB International, Wallingford, UK., pp: 99-119.

Sihen G, Girma A, Fikre L, Hindorf H. 2012. Coffee wilt disease (Gibberella xylarioides Heim and Saccas) in forest coffee systems of southwest and southeast Ethiopia. Plant Pathol. Plant Pathol. J. 11(1):10-17.

Sihen G, Girma A, Fikre L, Hindorf H. 2013. Population structure of Gibberella xylarioides

Heim and Saccas in Ethiopian forest coffee (Coffea arabica L.) systems. African Journal of Biotechnology Vol. 12(33), pp. 5157-5163,

Sylvain, P.G., 1958. Ethiopian coffee-its significance to world coffee problems. Econ. Bot., 12: 111-139.

Soto-Pinto, L., Perfecto, I. and Caballero-Nieto, J. 2002. Shade over coffee: Its effects on coffee berry borer, leaf rust and spontaneous herbs in Chiapas, Mexico. Agroforestry Systems 55: 37-45.

Tadesse, W.G., M. Denich, F. Gatzweiler, B. Girma and T. Demel, 2008. In situ Conservation of Genetic Resources of Wild Arabica Coffee in Montane Rainforests of Ethiopia. In: Coffee Diversity and Knowledge, Adugna, G., B.

Bellachew, T. Shimber, E. Taye and T. Kufa (Eds.). Agricultural Research Organization, Addis Ababa, Ethiopia, pp: 29-34.

Tesfaye, K., 2006. Genetic diversity of wild Coffea arabica populations in Ethiopia as a contribution to conservation and use planning. Ph.D. Thesis, University of Bonn, Bonn, Germany.

Van der Graaff, N.A., 1981. Selection of Arabica Coffee Types Resistant to Coffee Berry Disease in Ethiopia. Mededelingen Londbovwhogeschola, Wageningen, Page: 110.

Wrigley G., 1988. Coffee. Tropical Agriculture Series, Longman Science and Techinology, New York.

Waller, J.M., Bridge, P.D., Black, R. and Hakizal, G. 199). Characterization of the coffee berry disease 
pathogen, Colletotrichum kahawae Sp. Nov. Mycol. Res. 97: 989-994.

Wrigley, G.1988. Coffee. Tropical agriculture series. Longman Scientific and Technical Publisher, New York. pp 342-344.
Wondimu, M., 1991: Epidemiology and resistance of coffee leaf rust in Ethiopia. Ministry of Coffee and Tea Development. Addis Ababa/ Ethiopia.

Cite this Article: Getachew S (2017). Status of Forest Coffee (Coffea arabica L.) Diseases in the Afromontane Rainforest Areas of Ethiopia: A review. Greener Journal of Agricultural Sciences, 7(1): 019-031, http://doi.org/10.15580/GJAS.2017.1.122616223. 